\title{
Integration of Vigna mungo under Grewia optiva based Traditional Agroforestry System
}

\author{
Harish Sharma* and C. L. Thakur \\ Department of Silviculture and Agroforestry, Dr YS Parmar University of Horticulture and \\ Forestry, Nauni, Solan, 173230, India \\ *Corresponding author
}

\begin{tabular}{|l|}
\hline Ke y w or d s \\
Agrisilviculture, \\
Vigna mungo, \\
Crown spread, Tree \\
trunk, Grewia \\
optiva
\end{tabular}

The present study was conducted to inspect the effect of Grewia optiva Drummond based traditional agrisilviculture system on productivity of Vigna mungo. The crown spread of trees and distance from tree trunk was considered for quantifying effect of integration on the crop growth and production. Radial transects at right angle to each other were drawn for studying various growth and yield parameters at $1 \mathrm{~m}$, half the crown radius, perimeter of crown radius and outside the canopy (control) by plotting quadrat of $1 \times 1 \mathrm{~m}^{2}$. Results revealed that crown spread reduced the growth of Vigna mungo which consequently affected the yield of the crop suggesting light competition under heavier canopy. Further, distance from tree trunk was found to be positively correlated with growth and yield parameters suggesting better productivity of Vigna mungo outside tree canopy.

\section{Introduction}

Agroforestry is a farming system integrating crop and/or livestock with trees and shrubs in order to obtain economic, environmental, ecological and cultural benefits (Thevathasan et al., 2004). In the Himalayan region, a number of indigenous agroforestry systems have been familiar from Himachal Pradesh (Atul et al., 1990), out of which agrihortisilviculture, agrisilviculture and agrihorticulture are frequent. Agri-silviculture is a production technique which combines the growing of agricultural crops simultaneously with raised and protected forest crops. The assortment of trees on the edges of the agricultural field is farmer friendly and compatible. The fundamental roles of the woody perennials vary greatly in relation to the needs of the system and are multipurpose. MPTS are of particular significance in agroforestry systems, as they not only yield 
numerous products such as timber and fuelwood, fruits, animal fodder, medicines and poisons, fibres, rubber, tanning agents, mulch etc., but also may perform specific protective and soil amelioration functions. Multipurpose trees are defined as all woody perennials that are purposefully grown to provide more than one significant contribution to the production and/or service functions of a land-use system (Wood, 1991). Bhimal (Grewia optiva) is a medium sized multipurpose fodder tree growing in sub-tropical climates of northwestern Himalayas, fairly well distributed up to middle elevations (500-2500 masl) in India, Pakistan and Nepal (Semwal et al., 2002). The Bhimal fodder is quite important as it provides nutritious fodder during the lean season (Singh, 1982). The Bhimal fodder contains $17.35-21 \%$ crude protein, $17-21.51 \%$ crude fiber, $10.42-21.50 \%$ total ash, $4.21-6 \%$ ether extract and 40.41-50.24\% nitrogen free extract (Shankhyan and Bhagta, 2016) and do not contain tannins (Pandey et al., 2017). Green fodder yield from mature bhimal trees is reported to be $12-30 \mathrm{~kg}$. It is sparsely found in forest area and is mostly raised on bunds of agriculture fields. So, Grewia based agrisilviculture system is an important agroforestry system in North-Western Himalayan region keeping in view topographic and demographic features of the region. Vigna mungo (blackgram) is one of the most consumed grain legumes, cultivated mostly for food and medicinal properties promoting nutritional benefits for human health (Kundu et al., 2019).

Masha is a native of India and is cultivated as a major pulse crop almost throughout India. An important feature of the mashbean plant is its ability to set up the biological Nitrogen fixation process in root nodules by rhizobia (Mahmood and Athar, 2008; Mandal et al., 2009). Keeping in view the importance of Grewia optiva tree and Vigna mungo crop, the present investigation was carried out to quantify the effect of integration of Vigna mungo under Grewia optiva based traditional agroforestry system.

\section{Materials and Methods}

The present investigation was carried out in village Tikkar Jayog of Pacchad region of district Sirmour, Himachal Pradesh during kharif season in 2016-2017. The experimental site was sub-tropical region of Himachal Pradesh located between $30^{\circ} 48^{\prime} 47.22^{\prime \prime} \mathrm{N}$ latitude and $77^{\circ} 0727.6^{\prime \prime} \mathrm{E}$ longitude in NorthEast aspect and the elevation range was 1200$1500 \mathrm{~m}$ amsl. The crown spread of trees was considered major factor and was categorized into three crown classes viz., crown class I $[<3 \mathrm{~m}$ crown spread $(\mathrm{C} 1)]$, crown class II [3$6 \mathrm{~m}$ crown spread (C2)] and crown class III [ $>6 \mathrm{~m}$ crown spread (C3)] for quantifying the effect on the performance of the Vigna mungo. Radial transects at right angle to each other were drawn and the parameters were studied at $1 \mathrm{~m}\left[\mathrm{D}_{1}(1 \mathrm{M})\right]$, half the crown radius $\left[\mathrm{D}_{2}\right.$ $(\mathrm{H})]$, perimeter of crown radius $\left[\mathrm{D}_{3}(\mathrm{P})\right]$ and outside the canopy $\left[\mathrm{D}_{4}\right.$ (control)] by plotting quadrat of $1 \times 1 \mathrm{~m}^{2}$. Three trees from each crown class were selected for recording observations on different growth and yield parameters of Vigna mungo. In all there were 12 treatment combinations (three crown classes $\times$ four distances from tree trunk). The experiment was carried out in Randomized Block Design (Factorial) and standard methods were followed for the statistical analysis of the recorded observations on various growth and yield parameters.

\section{Results and Discussion}

\section{Plant Height (cm)}

Data obtained from present investigation suggests that plant height of Vigna mungo is significantly affected by crown class and distance from tree trunk. Considering crown 
classes (Table 1), the maximum plant height $(42.83 \mathrm{~cm})$ was obtained under crown class I while minimum $(39.58 \mathrm{~cm})$ under crown class III. Further, plant height increased with increased distance from tree trunk as depicted from the results (Table 2) and height at $1 \mathrm{~m}$ from tree trunk was $35.67 \mathrm{~cm}$ while height in open was $46.67 \mathrm{~cm}$. This may be due to the competition for resources between tree and crop. These results were consistent with the findings of Kumar, 1999 where competition and allelopathic effect were attributed for the reduced height near tree bole. Thakur and Singh et al., (2008) also reported higher plant height of Phaseolus mungo and Pisum sativum in open conditions and decrease in plant height with increasing shade intensities. Also, they reported increase in plant height with increasing distance from tree trunk. They attributed this to higher shade intensities immediately beneath the tree canopy.

\section{Number of branches per plant}

Branches were found maximum outside tree canopy in open condition. When only crown classes of the trees were considered maximum number of branches (11.50) were found in case of crown class I that differed significantly from crown class II and crown class III. Plants of Vigna mungo almost had double the number of branches (14.11) in open condition when compared with number of branches (7.33) at $1 \mathrm{~m}$ from tree trunk (Table 2). Hasan et al., (2012) also reported higher number of branches per plant in okra under controlled condition as compared to plants under tree. Also, there was increase in number of branches per plant with increased distance from tree. They attributed this decline to higher auxin production in shade condition which ultimately suppressed the growth of lateral branches. Kumar et al., (2015) also reported increase in number of branches of Vigna radiata under controlled condition as compared to canopy of Terminalia arjuna and
Mitragyna parvifolia and attributed this increase to higher light intensities under control condition.

\section{Number of flowers per plant}

Perusal of data depicts that number of flowers per plant was significantly affected by crown classes (Table 1) and distance from tree trunk (Table 2). Crown class I resulted in maximum (17.08) number of flowers per plant and crown class III resulted in minimum (14.33) number of flowers per plant which was at par with crown class II. Considering distance from tree trunk (Table 2), controlled condition resulted in maximum (20.11) number of flowers per plant while distance $1 \mathrm{~m}$ from tree trunk at par with half the crown radius resulted in minimum (11.44) number of flowers per plant.

This may be due to greater allocation of resources for vegetative growth under the influence of competition. Singh (2002) also reported higher number of flowers per plant under open conditions in case of Phaseolus mungo and Pisum sativum in morus based agroforestry system and reduction in number of flowers per plant with increase in size of canopy. Also, he reported increase in number of flowers per plant with increasing distance from tree trunk.

This was due to restricted amount of photosynthetically active radiations reaching to crops, which inturn reduces photosynthesis. Habib et al., (2012) reported increase in number of flowers per plant of okra with increase in distance from tree trunk. This was attributed to negative interaction between treecrop for growth resources.

\section{Leaf Area Index (LAI)}

Considering crown classes (Table 1), the Leaf Area Index differed significantly with maximum (1.63) LAI obtained under crown 
class I and minimum (1.37) under crown class III. Distance from tree trunk (Table 2) is positively correlated with LAI depicting increased LAI with increased distance from tree base.

Table.1 Effect of Crown classes of Grewia optiva Drummond on growth and yield parameters of Vigna mungo

\begin{tabular}{|c|c|c|c|c|c|c|}
\hline $\begin{array}{c}\text { Parameters Crown } \\
\text { class }\end{array}$ & $\begin{array}{c}\text { Plant } \\
\text { Height } \\
\text { (cm) }\end{array}$ & $\begin{array}{c}\text { Number of } \\
\text { branches/ } \\
\text { plant }\end{array}$ & $\begin{array}{c}\text { Number of } \\
\text { flowers / } \\
\text { plant }\end{array}$ & LAI & $\begin{array}{c}\text { Number } \\
\text { of pods/ } \\
\text { plant }\end{array}$ & $\begin{array}{c}\text { Number } \\
\text { of } \\
\text { grains/pod }\end{array}$ \\
\hline $\mathbf{C}_{\mathbf{1}}\left(\begin{array}{l}\mathbf{3} \mathbf{3 m} \text { Crown } \\
\text { Spread) }\end{array}\right.$ & 42.83 & 11.50 & 17.08 & 1.63 & 43.92 & 6.83 \\
\hline $\begin{array}{c}\mathbf{C}_{\mathbf{2}} \text { (3-6m Crown } \\
\text { Spread) }\end{array}$ & 40.83 & 10.00 & 14.50 & 1.43 & 39.50 & 6.08 \\
\hline $\begin{array}{c}\mathbf{C}_{\mathbf{3}} \text { (>6m Crown } \\
\text { Spread) }\end{array}$ & 39.58 & 9.58 & 14.33 & 1.37 & 36.00 & 5.50 \\
\hline C. $\mathbf{D}_{\mathbf{0 . 0 5}}$ & 2.04 & 0.96 & 2.27 & 0.09 & 3.96 & 0.84 \\
\hline
\end{tabular}

Table.2 Effect of distance from tree trunk of Grewia optiva Drummond on growth and yield parameters of Vigna mungo

\begin{tabular}{|c|c|c|c|c|c|c|}
\hline $\begin{array}{l}\text { Parameters Distance } \\
\text { from tree trunk }\end{array}$ & $\begin{array}{l}\text { Plant } \\
\text { Height } \\
\text { (cm) }\end{array}$ & $\begin{array}{c}\text { Number of } \\
\text { branches/ } \\
\text { plant }\end{array}$ & $\begin{array}{c}\text { Number of } \\
\text { flowers/ } \\
\text { plant }\end{array}$ & LAI & $\begin{array}{c}\text { Number } \\
\text { of pods/ } \\
\text { plant }\end{array}$ & $\begin{array}{c}\text { Number } \\
\text { of } \\
\text { grains/pod }\end{array}$ \\
\hline $\begin{array}{c}D_{1}\left(\begin{array}{c}1 \mathrm{~m} \text { from tree } \\
\text { trunk })\end{array}\right. \\
\text { the }\end{array}$ & 35.67 & 7.33 & 11.44 & 1.03 & 26.11 & 4.33 \\
\hline $\begin{array}{c}\mathrm{D}_{2} \text { (Half of crown } \\
\text { spread) }\end{array}$ & 37.56 & 7.44 & 12.11 & 1.11 & 27.22 & 5.44 \\
\hline $\begin{array}{c}\mathrm{D}_{3} \text { (Perimeter of } \\
\text { crown) }\end{array}$ & 44.44 & 12.56 & 17.56 & 1.75 & 50.67 & 6.78 \\
\hline $\mathrm{D}_{4}$ (Outside canopy) & 46.67 & 14.11 & 20.11 & 2.03 & 55.22 & 8.00 \\
\hline C. $D_{0.05}$ & 2.36 & 1.10 & 2.62 & 0.11 & 4.57 & 0.96 \\
\hline
\end{tabular}

LAI at $1 \mathrm{~m}$ distance from tree trunk was 1.03 and outside tree canopy was 2.03. Leaf Area Index may be less near tree trunk due to reduced light intensity. Sitaram (2010) also reported higher LAI of wheat plants under trees at greater spacing as compared with LAI of wheat plants under smaller spacing and attributed this to shading effect.

Gawali et al., (2015) reported highest LAI under sole cropping and increase in LAI with increase in tree spacing i.e. with increase in distance from tree base. They found that shading significantly reduced the amount of photosynthetically active radiations intercepted by the crop.

\section{Number of pods per plant}

With increase in size of crown the number of pods per plant of Vigna mungo decreased as depicted from number of pods in case of crown classes i.e. 43.92 under crown class I and 36.00 under crown class III (Table 1). Distance from tree also reduced number of pods per plant suggesting the negative effect of tree proximity on yield of crop (Table 2). The average number of pods per plant in open condition was 55.22 while at $1 \mathrm{~m}$ from tree trunk was 26.11. This is consistent with reduced number of flowers that ultimately affect the pod yield of the crop. Also, lower LAI of the plants under tree canopy may have 
reduced the resource use efficiency of the crop. Kumar (1999) also reported higher number of pods per plant of Glysine max under sole cropping as compared to that under tree canopy. Singh (2002) also reported higher number of pods per plant in Phaseolus mungo and Pisum sativum under open conditions and reduction in number of pods per plant with increase in size of canopy. Also, he reported increase in number of pods per plant with increasing distance from tree trunk and this was attributed to the reduced PAR under tree canopy as a result of shading. Kaur and Puri (2013) also found similar results that number of pods per plant was more for crop grown without trees as compared to crop under tree. Yogeshwari (2015) also reported higher number of pods per plant of Pisum sativum outside the tree canopy as compared to the distance closer to tree trunk.

\section{Number of grains per pod}

Taking into account the crown classes, the maximum (6.83) number of grains per pod was obtained under crown class I and minimum (5.50) under crown class III as depicted from table 1. Number of grains per pod was significantly affected by distance from tree trunk (Table 2). Treatment $\mathrm{D}_{4}$ (Outside tree canopy) resulted in the maximum (8.00) number of grains per pod while treatment $\mathrm{D}_{1}(1 \mathrm{~m}$ from tree trunk) resulted in minimum (4.33) number of grains per pod. This may be the result of the cumulative effect of tree shade on various growth parameters ultimately affecting the yield of the crop. Islam et al., (2008) also reported higher number of grains per pod in open condition as compared to that of reduced light conditions. Competition for various resources under the influence of tree shade may be a reason for the reduced number of the grains. Tanni et al., (2010) also reported similar results that number of seeds per pod was higher in case of soyabean plants outside the tree canopy and with increase in distance from tree base number of seeds per pod increased. Mohammed (2012) also reported higher number of grains per pod of various pulse crops under controlled conditions (i.e. without tree) as compared to number of grains per pod under trees planted at different spacings. The reduction in yield of the crops associated was attributed to nutrient, moisture and light competition between trees and associated crops.

\section{Acknowledgement}

The authors are grateful to Dr Yashwant Singh Parmar University of Horticulture \& Forestry, Nauni, Solan, Himachal Pradesh for providing all the required facilities for conducting the present investigation. Also, farmers of study area are highly acknowledged for their support and cooperation.

\section{References}

Atul, P., and Khosla, P.K. 1990. Classification of traditional agroforestry system. In: Proceeding IUFRO, $19^{\text {th }}$ World Forestry Congress, Montreal. pp. 2427.

Gawali, A., Puri, S., and Swamy, S.L. 2015. Evaluation growth and yield of wheat varieties under Ceiba pentandra (L) based agrisilviculture System. Universal Journal of Agricultural Research 3:173-181.

Habib, M.A., Mondol, M.A., Alam, Z., Hasan, M.R., and Wadud, M.A. 2012. Interaction effect of four years old Xylia dolabriformis tree on the growth and yield of summer vegetables. Journal of Agroforestry Environment 6:21-25.

Hasan, M.R., Akter, A., Alam, Z., and Wadud, M.A. 2012. Indian spinach and Okra cultivation along with Swietenia hybrid a tree as agroforestry practices. Journal 
of Agroforestry Environment 6:119124.

Islam, K.K., Pervin, M.J., Rashid, M.H., Mondol, M.A., and Rahim, M.A. 2008. Performance of winter vegetables grown under coconut lemon based multistrata agroforestry system. Tropical and Subtropical Agroecosystems 8:165-170.

Kaur, R., and Puri, S. 2013. Productivity and nutrient dynamics in Vigna mungo and Triticum aestivum growing in an agroforestry system in Himachal Pradesh. International Journal of Botany and Research 3:43-50.

Kumar, M. 1999. Tree crop interaction studies in agroforestry system- productivity, moisture and nutrient dynamics. Ph. D Thesis. Department of Silviculture and Agroforestry, Dr. YS Parmar University of Horticulture and Forestry, Nauni, Solan. 89 p.

Kumar, S., Behera, L.K., Patil, N.S., and Jadega, D.B. 2015. Growth and yield of Vigna radiata (L.) under Terminalia arjuna and Mitragyna parvifolia based agrisilvicultural system. Journal of Applied and Natural Science 7:758762.

Kundu, A., Singh, P.K., Dey, A., Ganguli, S., and Pal, A. 2019. Complex molecular mechanisms underlying MYMIVresistance in Vigna mungo revealed by comparative transcriptome profiling. Scientific Reports 8858: 1-13.

Mahmood, A., and Athar, M. 2008. Cross inoculation studies: Response of Vigna mungo to inoculation with rhizobia from tree legumes growing under arid Environment. International Journal of Environmental Science and Technology 5: 135-139.

Mandal, S., Mandal, M., and Das, A. 2009. Stimulation of indoleacetic acid production in a Rhizobium isolate of Vigna mungo by root nodule phenolic acids. Archives of Microbiology 191: 389-393.

Mohammed, M. 2012. Effect of tree spacing and integrated nutrient management on productivity of pulse crops in poplar (Populus deltoides bartr.) based agrisilviculture system. $\mathrm{Ph}$. D Thesis. Department of Silviculture and Agroforestry, Dr. YS Parmar University of Horticulture and Forestry, Nauni, Solan. 183p.

Pandey, L.N., Tiwari, M.R., Bahadur, B., Baskota, N., and Banjade, J.N. 2017. Feeding Response of Tree Fodder Bhimal (Grewia optiva) on Growth Performance of Castrated Male Goats. Journal of Nepal Agricultural Research Council 3: 1-5.

Sankhyan, H.P., and Bhagta, S. 2016. Fodder quality analysis of open pollinated seedling seed orchard of Grewia optiva Drommond. The Bio Scan. 11(2): 709713.

Semwal, R.L., Maikhuri, R.K., Rao, K.S., Singh K., and Saxena, K.G. 2002. Crop productivity under differently lopped canopies of multipurpose trees in Central Himalaya, India. Agroforestry Systems. 56: 57-62.

Singh, L., Ghosh, L., Bargali, S.S., and Saxena, R.R. 2008. Influence of naturally occurring trees on field bunds and their impact on yield parameters of paddy crop. Range Management and Agroforestry 29: 134-137.

Singh, S. 2002. Effect of shade intensities on Phaseolus mungo and Pisum sativum in Morus based agroforestry system under rain fed conditions. M. Sc. Thesis. Department of Silviculture and Agroforestry, Dr. YS Parmar University of Horticulture and Forestry, Nauni, Solan. 89p.

Singh, R.V. 1982. Fodder Trees of India. Oxford and IBH Publ. Co., New Delhi. $663 p$. 
Sitaram, S.S. 2010. Effect of tree species, spacing and fertility levels on soil properties, growth and yield of wheat under agroforestry system in tarai region. M.Sc. Thesis, G.B. Pant University of Agriculture and Technology. 190p.

Tanni, A.D., Wadud, M.A., Sharif, M.O., Mondol, M.A., and Islam, M.T. 2010. Influence of Lohakat (Xylia dolabriformis) tree on the growth and yield of four winter crops. Journal of Agroforestry and Environment 4:6367.

Thevathasan, N.V., Gordan, A.M., Simposon, J.A., Reynolds, P.E., Price, G.W., and Zhang, P. 2004. Bio-physical and ecological interactions in a temperate tree-based intercropping system.
Journal of Crop Improvement, 12: 339363.

Wood, P.J., and Burley, J. 1991. A tree for all reasons-The introduction and evaluation of multipurpose trees for agroforestry. International Centre for Research in Agroforestry, United Nations Avenue, P.O. Box 30677, Nairobi, Kenya. 154p.

Yogeshwari. 2015. Crop production and physico-chemical characteristics of soils under Toona ciliata M. Roem trees in mid hill conditions of Himachal Pradesh. M. Sc. Thesis. Department of Silviculture and Agroforestry, Dr. YS Parmar University of Horticulture and Forestry, Nauni, Solan. 97p.

\section{How to cite this article:}

Harish Sharma and Thakur, C. L. 2019. Integration of Vigna mungo under Grewia optiva based Traditional Agroforestry System. Int.J.Curr.Microbiol.App.Sci. 8(12): 64-70. doi: https://doi.org/10.20546/ijcmas.2019.812.010 